\title{
Quantification of tributaries contributions using a confluence-based sediment fingerprinting approach in the Canche river watershed (France).
}

Edouard Patault ${ }^{a, b, *}$, Claire Alary $^{a}$, Christine Franke $^{b}$, Nor-Edine Abriak $^{a}$

aIMT Lille Douai, Univ. Lille, EA 4515 - LGCgE - Civil Engineering and Environmental Department, F-59000 Lille, France

${ }^{b}$ MINES ParisTech, PSL Research University, Center of Geosciences, 35 rue Saint-Honoré, 77305 Fontainebleau Cedex, France

*Now at: Normandie Univ, Rouen, UNIROUEN, UNICAEN, CNRS, M2C, FED-SCALE, Rouen, France

E-mail address: edouard.patault@imt-lille-douai.fr / edouard.patault1@univ-rouen.fr (E.Patault) 


\section{Abstract}

Since a few years, land use management aims to reduce and control water erosion processes in watersheds but there is a lack of quantitative information on the contribution of the sources of transported sediment. This is most important in agricultural areas where soils are sensitive to erosion. The geology of these areas is often characterized by large expanses of relatively homogeneous quaternary silts. The possibility of distinguishing the sources of erosion according to their geological substratum is thus very delicate. This information is important because its lack can lead to the mis-implementation of erosion control measures. To address this request, a confluencebased sediment fingerprinting approach was developed on the Canche river watershed $\left(1274 \mathrm{~km}^{2}\right.$; northern France), located in the European loess belt, an area that is affected by diffuse and concentrate erosion processes. Suspended particulate matter was collected during five seasonal sampling campaigns using sediment traps at the outlet of each tributary and confluence with the main stream of the Canche river. The final composite fingerprint was defined using physico-chemical and statistical analyses. The best tracer parameters for each tributary were selected using stepwise discriminant function analyses. These parameters were introduced into a mass balance mixing model incorporating Monte-Carlo simulations to represent the uncertainty. Estimates of the overall mean contributions from each tributary were quantified at different temporal scales. The annual sediment flux tributaries contributions range from 3 to $22 \%$ at the outlet of the Canche river, and annual sediment flux range from 0.87 to $40.7 \mathrm{kt} \mathrm{yr}^{-1}$. The Planquette and the Créquoise tributaries appear to be those producing the largest sediment flux. In contrast, tributaries with the highest number of erosion control on their area exhibit the lowest values of sediment flux. Our results indicate a positive impact of recent land management policies in the Canche river watershed.

Keywords: sediment fingerprinting; physico-chemical tracers; tributaries; mixing model; watershed management; Northern France 


\section{Introduction}

Information on the origin of sediment transfer in river systems is essential for watershed management. This is a complex task considering that suspended material may come from different diffuse sources and their contribution may vary over time and space as a consequence of varying erosion processes (Haddadchi et al., 2013). Indirect approaches exist to identify sediment sources (field surveys, river monitoring) but they are hampered by spatial and temporal sampling problems (Collins \& Walling, 2002). Since several years, direct approaches such as the "sediment fingerprinting" method (e.g. Walling \& Woodward, 1992; Collins et al., 2001; Krein et al., 2003; Motha et al., 2004; Martínez-Carreras et al., 2010; Evrard et al., 2011; Lamba et al., 2015) have been commonly applied. These approaches attempt to quantify the contributions of sediment sources at variable spatial scales: from the river section to the catchment scale. The procedure consists on the characterization of the potential sediment sources by a comparison of their bio-geo-physico-chemical properties to the transported fluvial material. The properties that have been used in previous research include sediment color (e.g. Krein et al., 2003; Poulenard et al., 2009; Martínez-Carreras et al., 2010), magnetic properties (e.g. Russell et al., 2001; Motha et al., 2004), chemical composition (e.g. Collins et al., 1997; Carter et al., 2003; Collins et al., 2012; Theuring et al., 2015), environmental radionuclides (e.g. Evrard et al., 2013; Du \& Walling, 2016; Le Gall et al., 2016), and particle size (e.g. Krein et al., 2003).

There is a consensus that the use of a single parameter is not sufficient, and that a combination of tracers must be used to identify sediment sources (Walling et al., 1993; Collins and Walling, 2002). Because of the heterogeneity of catchments, a large panel of tracers and statistical methods to identify the best combination of parameters that discriminates the sediment sources are generally used (e.g. Collins et al., 1997; Collins et al., 2012; Palazón et al., 2015; Nosrati et al., 2018). Selected data is injected in a mixing model to quantify the contribution of each source to the target sediment. The literature describes different mathematical form of mixing models: e.g. the modified Collins model algorithm, the Hughes mixing model, the Landwehr model (Collins et al., 1997; Motha 
et al., 2003; Hughes et al., 2009; Collins et al., 2010; Devereux et al., 2010; Gellis and Walling, 2011; Haddadchi et al., 2013). Uncertainties associated to the results of the mixing model are evaluated using mathematical algorithms. In studies dealing with the sediment fingerprinting approach, machine learning algorithms are often applied such as the Bayesian mixing model (Nosrati et al., 2018), Monte-Carlo simulations (Hughes et al., 2009; Lamba et al., 2015; Vale et al., 2016; Pulley and Collins, 2018), classification and regression trees (CART model; Choubin et al., 2018).

While the sediment fingerprinting method has largely contributed to the quantification of sources of sediment input for different watersheds around the world, recent discoveries showed that some scientific questions still need to be resolved (e.g. Smith et al., 2015). Some studies have shown that the selection of sources and sediment targets in a catchment may have important implications for the interpretation of the results : highly erodible areas may have a disproportionate effect on tracer concentrations (Wilkinson et al., 2013) and nearby sources may have larger contributions for a given point on a river than distant sources (Haddadchi et al., 2015). It is also important to pre-identify the sources contributing to the sediment flux as an un-sampled source can strongly bias the results (Smith et al., 2015). Thus, the selection of tracers is an important issue in this approach: uncertainties in the prediction of source contributions decrease by increasing the number of trace parameters (Sherriff et al., 2015). Predicted contributions may be different depending on the choice of tracers (Pulley et al., 2015). The conservative behavior of tracers may also introduce bias in interpretations (Sherriff et al., 2015) therefore a careful tracer selection procedure is recommended (Kraushaar et al., 2015). The type and the structure of the mixing model may also affect the results due to different mathematical approaches (see review of Haddadchi et al., 2013; and references therein). Cooper et al. (2014) showed that the estimation of the source contributions varies up to $21 \%$ between the different models. Laceby and Olley (2015) suggested that correction factors (particle size or organic matter content) did not significantly improve the results. 
suggested by Koiter et al. (2013) and are supported by observations published by Fryirs et al. (2013).

They suggest that sedimentary transport pathways cannot be assumed to be directly connected between sources and outlets, but include barriers or buffers that disrupt sediment transfer. Recently, Li et al. (2019) show that some element concentrations and their relative contributions to the surface sediments were relevant to sediment transport processes and the related flow paths, because of their association with different types of grains. To address this challenge, the so-called "tributary tracing" or "confluence tracing" approaches were recently developed (e.g. Vale et al., 2016; Nosrati et al., 2018). The latter concept consists in the consideration of tributary upstream sediments as potential sources for downstream sediments, and this approach removes a significant proportion of the impact of potential chemical enrichment on sediments due to particle size variations (Laceby et al., 2017).

In the Canche river watershed in Northern France, most natural hazards are related to mudflow and flooding. Mudflow causes significant damages to infrastructure that induce high economic costs. Since 2000, environmental policies are designed to reduce erosion by runoff in the Canche river watershed by implementing hard and soft erosion control measures, such as dams, retention pools, ditches or fascines. However, so far few information is available on the evaluation of the efficiency of these environmental policies.

The main goal of this study is to assess the suitability of the confluence-based sediment fingerprinting approach in a relatively homogeneous environmental context and to quantify the contribution of the different tributaries draining the studied agricultural watershed. As this watershed is very sensitive to erosion processes and environmental policies try to reduce the sediment input in the Canche river, this work also proposes an application of the confluence-based sediment fingerprinting approach to evaluate the possible effect of environmental policies on erosion reduction. 


\section{Material \& Methods}

\subsection{The Canche river watershed}

The Canche river watershed ( $1274 \mathrm{~km}^{2}$; lat.: $50^{\circ} 25^{\prime} 53^{\prime \prime} \mathrm{N}$, long.: $2^{\circ} 02^{\prime} 24^{\prime \prime} \mathrm{E}$; Fig. $\left.1 \mathrm{~A}\right)$ is situated in the European loess belt in Northern France and is characterized by oceanic climate conditions. The mean annual temperature is $11^{\circ} \mathrm{C}$ and the mean annual rainfall comprises $1000 \pm 150 \mathrm{~mm}$. Altitudes range from $0 \mathrm{~m}$ at the catchment outlet to $207 \mathrm{~m}$ in the upstream areas and catchment slopes are commonly in the range $2-3 \%$ (Fig. 1B). The watershed is characterized by a meandriform drainage network dominated by the Canche river $(88 \mathrm{~km})$ and seven tributaries. The watershed drains Quaternary loess on the chalky grounds of the Seno-Turonian.

The Canche river watershed is dominated by agricultural land use, consisting of $80 \%$ arable lands (Fig. 1C). The watershed is affected by mudflows, mainly due to diffuse and concentrate erosion on arable lands that induce an important economic cost for the local communities (Patault, 2018). Moreover, surface soils are affected by water erosion leading to a highly variable specific sediment yield at the outlet of the river. The annual sediment export ranged from 29 to $185 \mathrm{kt}$ between 1999 and 2016 according to the local water agency (Agence de l'Eau Artois-Picardie, 2016).

The mean annual discharge for the Canche river is estimated to $21 \mathrm{~m}^{3} \mathrm{~s}^{-1}$ with contributions from the following main tributaries: Ternoise $\left(7 \mathrm{~m}^{3} \mathrm{~s}^{-1}\right)$, Planquette $\left(1.5 \mathrm{~m}^{3} \mathrm{~s}^{-1}\right)$, Créquoise $\left(2 \mathrm{~m}^{3} \mathrm{~s}^{-1}\right)$, Bras de Bronne $\left(2 \mathrm{~m}^{3} \mathrm{~s}^{-1}\right)$, Course $\left(4 \mathrm{~m}^{3} \mathrm{~s}^{-1}\right)$, Dordogne $\left(2.5 \mathrm{~m}^{3} \mathrm{~s}^{-1}\right)$, and Huitrepin $\left(2 \mathrm{~m}^{3} \mathrm{~s}^{-1}\right)$. The flow discharge was quantified using a low-frequency monitoring station, based on water level estimations, in the Ternoise, Course, and Canche river. Flow discharge for the ungauged catchments $Q_{\text {ungauged }}$ was calculated assuming similar rainfall and hydrological regimes in the entire watershed. Values were extrapolated from the closest monitoring station by multiplying the value $Q_{\text {gauged }}$ with the appropriate fraction related to the ratio between the closest catchment area $\left(A_{\text {ungauged }}\right)$ and the catchment area at the monitoring station $A_{\text {gauged }}$ : 


$$
Q_{\text {ungauged }}=Q_{\text {gauged }} \times \frac{A_{\text {ungauged }}}{A_{\text {gauged }}}
$$

with $Q$ representing the discharge in $\mathrm{m}^{3} \mathrm{~s}^{-1}$ and $A$ as the area of the catchments in $\mathrm{km}^{2}$.

According to Andréassian et al. (2012), this method provides robust results for ungauged catchments. Cross validation with the high-frequency monitoring station on the Canche river watershed evaluated a $17 \%$ associated error (Fig. S1).

\subsection{Sediment sampling}

Suspended particulate matter (SPM) were collected using sediment traps installed at each tributary outlet and each confluence with the Canche river (Fig. 1D). Sampling campaigns were conducted in winter 2015 , winter 2016, spring 2016, summer 2016, and autumn 2016. A total of 65 samples was collected. More details on the sampling devices, exact sampling periods, and site positions are available in Figure 2 and Table S1.

The samples consist of recently suspended solids transported in the different tributaries. Sediment was sampled using an experimental device adapted from previous studies (described by Tessier (2003) and Kayvantash et al. (2017)). The sediment traps (Fig. 2) consist of 2 I polyethylene bottles, perforated at $5 \mathrm{~cm}$ from the top with two opposite holes (diameter $5 \mathrm{~cm}$ ). The bottle is attached to the river bank with a rope and deposited in the channel. The device is hold in place using either an additional rope or a combination of rope and a wooden beam. The whole device is weighted vertically in the water column using ballast that is adapted to the river flow speed. Traps usually captured between 50 and $100 \mathrm{~g}$ of sediments during $\sim 5$ days water expose. Recent work in the Seine river in France, observed that there is no significant grain size selection depending on the position of the bottle in the river channel (Kayvantash, 2016; Kayvantash et al., 2017). 


\subsection{Sedimentological and geochemical analysis}

All samples were analyzed to obtain particle size distribution and elemental composition. Grain size analyzes were performed using a Beckman Coulter LS 13320 laser particle sizer. All samples were initially oven-dried at $30^{\circ} \mathrm{C}$ for $72 \mathrm{~h}$ and sieved to $2 \mathrm{~mm}$ to remove any coarser debris, such as leafs and roots, that could distort further measurement. Two grams of sediment were mixed with $100 \mathrm{ml}$ of ultrapure water and were stirred during 5 min using ultrasonic dispersion to homogenize the sample. Each solution was analyzed in triplicates to validate the measurement.

The analysis of the elemental composition was carried out after acid mineralization in a microwave oven. 22 reactors were used for mineralization, $0.250 \mathrm{~g}$ of a sample were injected in 18 reactors, 2 reactors are used as references with TH2 (reference sediment material) to test the validity of the analysis by comparison with referenced measurements, and 2 blank reactors (without addition of solid material) are used to ensure non-contamination during preparation. For each reactor, $1 \mathrm{ml}$ of nitric acid $\left(\mathrm{HNO}_{3}\right), 3 \mathrm{ml}$ of hydrochloric acid $(\mathrm{HCl})$, and $0.5 \mathrm{ml}$ of water $\left(\mathrm{H}_{2} \mathrm{O}\right)$ is added to the sediment. The determination of the major elements in the liquid phase (Al, $\mathrm{Ca}, \mathrm{Fe}, \mathrm{K}, \mathrm{Mg}, \mathrm{Mn}, \mathrm{Na}, \mathrm{P}, \mathrm{S}, \mathrm{Si}, \mathrm{Sr}, \mathrm{Ti}$, $\mathrm{Zn)}$ was performed using an inductively coupled plasma atomic emission spectrometer (ICP-AES; ICAP 7400 Thermo Fischer Scientific). The determination of the trace elements ( $\mathrm{As}, \mathrm{Ba}, \mathrm{Bi}, \mathrm{Cd}, \mathrm{Ce}, \mathrm{Co}, \mathrm{Cs}$, $\mathrm{Cr}, \mathrm{Cu}, \mathrm{La}, \mathrm{Li}, \mathrm{Mo}, \mathrm{Ni}, \mathrm{Pb}, \mathrm{Rb}, \mathrm{Sb}, \mathrm{Sc}, \mathrm{Se}, \mathrm{Sn}, \mathrm{Th}, \mathrm{Tl}, \mathrm{U}, \mathrm{V})$ in the samples was carried out using an inductively coupled plasma mass spectrometer (ICP-MS; PerkinElmer NexION 300x).

\subsection{Sediment fingerprinting procedure}

Several analytical and statistical steps were used, using the model Sed_Sat-v1.0 (Gorman Sanisaca el al., 2017) to determine which tracers are most significant in defining tributaries and quantifing the relative contributions of tributaries to the suspended sediment samples. The model is written using the statistical software $R$ (R Core Team, 2013) and Microsoft Access $(\mathcal{C}$ is used as a user interface.

2.4.1 Test for univariate normal distribution 
variables. As a first step of the model, all variables were tested for normality, using the Shapiro-Wilk

148 test (Shapiro and Wilk, 1965), to determine if the raw concentration values are normally distributed

149 within each source group. All variables that were not normally distributed were tested again for 150 normality after transformation using the Tukey Ladder of Powers transformations (Table S2; Tukey, 151 1977).

\subsubsection{Outlier test}

The average and the standard deviation within each source group for each tracer were determined. If the tracer value for a given source sample exceeded three times the standard deviation of the average value, the sample was considered an outlier and removed from the tracer set (Wainer, 1976; in Gellis et al., 2013).

\subsubsection{Range test}

A condition for sediment fingerprinting is that the tracer concentration values in the target dataset must be conservative and do not change during transport (Walling et al., 2002). A range test was used to determine if for any given tracer, the target samples lie within the range of the tracer concentration values in the source dataset. Any tracers that fail to satisfy this condition within the measurement error (10\% of each fluvial sample's tracer value) are considered non-conservative and were removed from dataset (Gellis et al., 2013; Gorman Sanisaca et al., 2017).

\subsubsection{Stepwise Linear Discriminant Function Analysis (DFA)}

To create the final group of tracers that differentiate the tributaries, a stepwise linear discriminant function analysis (DFA) was performed. The stepwise linear DFA identifies tracers that yield the greatest separation between the tributaries and rejects variables that do not contribute based on the minimization of the Wilk's lambda criterion. The closer the Wilk's lambda statistic is to 

expressed as:

$$
\sum_{i=1}^{n}\left\{\left[C_{i}-\left(\sum_{i=1}^{m} P_{S} S_{i}\right)\right] / C_{i}\right\}^{2} W_{i}
$$

Where $C_{i}$ is the concentration of tracer $i$ in the target sample; $P_{S}$ is the optimized percentage of contribution source type (s); $S_{i}$ is the mean concentration of tracer $i$ in source $s$; $W_{i}$ is the weighting factor for tracer $i ; n$ is the number of tracers comprising the optimum composite fingerprint; and $m$ is the number of sediment source types.

The model adheres to two constraints that must be satisfied to produce realistic values, which are: each source group proportion is constrain to a positive value between 0 and 1 , and is

$$
0 \leq P_{S} \leq 1
$$

$$
\sum_{s=1}^{n} P_{s}=1
$$



power, based on the relative discriminatory power of each individual tracer provided by the results of the stepwise DFA. The weighted values ensure that tracers with higher discriminatory power are optimized in the mixing model. The weighting for each tracer that passed the stepwise DFA is calculated as follows:

$$
W_{i}=\frac{P_{i}}{P_{o p t}}
$$

193 Where $P_{i}$ is the percentage of correctly classified source samples using tracer $i$ and $P_{\text {opt }}$ is the 194 percentage of correctly classified source samples using tracer with the lowest $P_{i}$. the Canche river. Tributaries percentages are presented for each sampling campaign and were also used to quantify the sediment yield of each tributary. 

sediment fingerprinting results produced by the mixing model. The Monte-Carlo simulation randomly removes one sample from each of the eight source type groups and the mixing model is run without these samples. The Monte-Carlo simulation is run 1,000 times on each fluvial sample (Gellis et al., 2015). For each of the 1,000 iterations, the minimum-maximum, and the average sediment source for each tributary are determined. The robustness of the final set of tributaries and tracers is defined using the difference between the final mixing model results, the average, the minimum and maximum source percentage results produced by the Monte-Carlo simulation (Gellis et al., 2013). acceptable range of uncertainty (Haddadchi et al., 2014; Palazón et al., 2015; Pulley and Collins, 2018). Thus, we test the robustness of the employed mixing model using tracer values of virtual sample mixtures. These virtual samples consists in hypothetical sediment provenance of equal input from each tributary, and subsequently were mathematically calculated at each confluence. The hypothetical composition of the virtual sample mixtures were then compared to the un-mixed composition calculated by the model. The accuracy of the modelling approach was tested based on the Mean Absolute Error (MAE) at each confluence:

$$
M A E=\frac{\sum_{j-1}^{m}\left|X_{j}-Y_{j}\right|}{m}
$$

Where $X_{j}$ is the hypothetical percentage of each source $(j)$ in mixtures sediments, $Y_{j}$ is the calculated contribution of each source and $m$ is the number of sources $(m=8)$.

\subsection{Efficiency of erosion control measures}

Information on the locations of erosion control measures (runoff retention pools, check dams, fascine, etc.) in the Canche river watershed were provided by the Chamber of Agriculture using the Database RUISSOL (Chambre d'Agriculture Nord-Pas-de-Calais, 2013). For each tributary, 

their respective area:

$$
E C I_{i}=\frac{\sum_{1}^{n} E C M_{i}}{A_{i}}
$$

With $E C M_{i}$ presenting the number of erosion control measures installed on the catchment $i$; and $A_{i}$ as the area of the catchment $i$ in $\mathrm{km}^{2} . E C I_{i}$ was then compared to the annual tributary sediment yield (in kt) calculated using the mixing model and Monte-Carlo simulations.

\section{Results}

\subsection{Sediment analysis}

The particles size analysis highlights the absence of significant differences between the D50 (median particle size) of the tributaries $(60.3 \pm 6.7 \mu \mathrm{m})$ in comparison to the sediment sampled at each confluence in the Canche river $(67.9 \pm 10 \mu \mathrm{m}$; Fig. 3). A t-test between the tributaries and the confluences did not show any significant difference between their D50 ( $p$-value $=0.107)$. Thus for further model analyses, no particle size correction was applied considering that no significant particle size effect affects the direct comparison between tributaries and confluences samples.

The geochemical analysis showed evidence of some element concentration heterogeneities for the different sources (Fig. 4). The range of element concentrations is particularly high for some major elements (Ca: $22054.9-42314 \mu \mathrm{g} \mathrm{g}^{-1}$; S: $1013.4-4723.3 \mu \mathrm{g} \mathrm{g}^{-1}$ ) and trace elements (Ce: $29.4-$ $55 \mu \mathrm{g} \mathrm{g}^{-1}$; La $16.6-30.7 \mu \mathrm{g} \mathrm{g}^{-1}$ ). The element concentrations for the confluences are generally in the range of the values observed for the tributaries. Sometimes the range of the values for confluences is higher than the range for tributaries ( $\mathrm{Bi}, \mathrm{Ca}, \mathrm{Cu}, \mathrm{Na}$, and $\mathrm{Sr}$ ). Even though the Canche river catchment exhibits a homogeneous geology, major and trace elements seem to have a non-negligible potential for discriminating sources and quantify their contribution to the suspended sediment sampled at 
each confluence. Considering this first approach, robust statistical analyses are needed to explore the entire dataset.

\subsection{Final composite fingerprint}

The first analysis consisted in the identification of outliers in the source dataset. Results showed no outliers for any tributary. Thus, all tracer parameters were kept for further analysis. Table S3 presents the results of the bracket test and shows that different elements were considered conservative at each sub-basin outlet (spatial sediment sources). Tracers were considered conservative when, for any given tracer, no significant changes during transport between upstream sources and downstream sediment sampling sites occurred. At each confluence, more than twenty tracers were considered conservative and kept for further analysis except for the confluence C2 where only nine tracers were considered conservative. Cross validation using bi-plots of tracers of tributary and confluence samples confirmed the conservativeness/non-conservativeness of these tracers (Fig.S2). For the pairs of tracers that are significantly correlated $\left(R^{2}>0.8\right)$ within the tributary sample dataset, the correlation is maintained when adding the confluence dataset suggesting a high degree of conservatism. For other tracer pairs, the correlation is not maintained when adding the confluence sediment samples, which suggests a non-conservative behaviour. These tracers were correctly identified by the range test and were removed from further analysis.

With the remaining set of tracers, the stepwise DFA produced a final composite fingerprint at each confluence that provides sources discrimination (Table 2). The final composite fingerprint includes different chemical tracers that minimizes the Wilk's lambda criterion and that maximizes the source sample discrimination. At each confluence, the proposed final composite fingerprint correctly classified between 53 and $100 \%$ of the source samples in their correct affiliation. The classification is better for the confluence $\mathrm{C} 1, \mathrm{C} 3$, and $\mathrm{C} 4$, reaching values from 69 to $100 \%$. Chemical tracers selected for the different final composite fingerprint principally include transition metals (44\%), metalloids and alkaline earth metals (32\%), and other element classes (24\%; alkali metals, nonmetals, 
lanthanides and actinides). Selected tracers are appropriate, considering the geochemical background level of the Canche watershed and the point or non-point discharges mainly induced by agricultural activity.

\subsection{Monte-Carlo simulations}

The range of Monte-Carlo simulations results show difference of $\pm 10 \%$ in comparison with the average resulting from the mixing model (Fig.S3). The relative contributions calculated by the mixing model at each confluence are considered robust, despite a large spread of the Monte-Carlo results between minimum and maximum values can be observed for some confluences (C2 - C5). Nevertheless, the increase of sources, after confluence $\mathrm{C5}$, tends to decrease the uncertainties in the Monte-Carlo simulations.

Modelling results using virtual mixtures at each confluence confirm that all sources are well recognized by the mixing model (Fig.5). The MAE values are relatively low and are thus considered acceptable, ranging from 0.93 to $6.36 \%$, with a slight variability within each confluence $(\mathrm{min}=0.27$ and $\max =7.57 \%)$. The results are considered robust, even with a high number of sources at the last confluence $(m=8$ and MAE $=2.1 \%)$. This test supports the hypothesis that the applied methodology is reliable.

\subsection{Annual tributaries contributions}

Annual tributaries relative contributions could be calculated using the four campaigns performed during the year 2016 (Fig. 6). The results show in general a high and persistent relative contribution of the Planquette and the Créquoise along the main channel. For example, the relative contribution of the Planquette at point C3 is $19 \%$ and $21 \%$ at point C7. The contributions of the upstream part of the Canche river and the Ternoise are particularly high in the upstream areas (33 and $49 \%$ at point $\mathrm{C} 2$ ) but tend to decrease as we approach the outlet of the catchment (12 and 3\% at point (7). The relative contribution of the Course seems important in the downstream area except for the point $\mathrm{C} 6$ that may have encountered a mis-classification of the source samples (C5: $24 \%$-; C6: 
3\%; C7: 15\%). The relative contributions of the downstream tributaries (Dordogne and Huîtrepin) are generally moderate as their outlet is closer to the sampling point. These average results over four sampling campaigns corresponding to the hydrologic year 2016 seem consistent if we consider the relative hydrological contributions of each tributary to the Canche main stream and the length of the main channel. Spatial variations show that along the Canche river catchment, the sedimentary signatures of the upstream tributaries tend to decrease as we approach the downstream indicating a possible effect of storage and/or dilution of the sediment flux.

\subsection{Tributaries sediment yield}

Considering the information provided by the Artois-Picardie Water Agency, the annual sediment yield of the Canche river catchment ranges from 29 to $185 \mathrm{kt} \mathrm{yr}^{-1}$ since 1999 . The relative contributions were previously evaluated at point C7 as follows: Canche $12 \%$, Ternoise $3 \%$, Planquette 22\%, Créquoise 20\%, Bras de Bronne 7\%, Course 15\%, Dordogne 6\%, and Huîtrepin 15\%. Based on the lower and upper boundaries of the annual sediment yield, the range of the sediment yield and specific sediment yield from tributaries to the main stream were calculated (Table S3). The highest sediment yields were calculated for the Créquoise and the Planquette, $5.8-37 \mathrm{kt} \mathrm{yr}^{-1}$ and respectively $6.38-40.7 \mathrm{kt} \mathrm{yr}^{-1}$. The lowest sediment yields were estimated for the Ternoise $(0.87-$ $\left.5.55 \mathrm{kt} \mathrm{yr}^{-1}\right)$, the Bras de Bronne $\left(2.03-12.95 \mathrm{kt} \mathrm{yr}^{-1}\right)$, and the Dordogne $\left(1.74-11.1 \mathrm{kt} \mathrm{yr}^{-1}\right)$.

\subsection{Impact of erosion control measures}

Considering that catchment stakeholders implemented 1590 erosion control measures in the Canche river watershed since 2000 , this study proposes to evaluate their efficiency using the defined erosion control index $\left(E C I_{i}\right)$ and the sediment yield of each tributary previously calculated. Here, we solely implement the total number of the measures installed, as considered parameter in the $E C I_{i}$. We precise that there exist several types of erosion control measures in the field (fascines, grass strips, hedges, ponds, dams, nozzles, ditches). Nevertheless, the ratio between the different types of measures is similar whatever the treated catchment. Our results show a positive impact of the 
installation of erosion control measures. Catchments characterized by flow discharge around $1 \mathrm{~m}^{3} \mathrm{~s}^{-1}$ with the highest $E C I_{i}$ (Dordogne, Bras de Bronne, Huîtrepin) exhibit low values of sediment yield

(Fig. 7). For catchments with similar fluxes and for which few erosion control measures were installed so far (Créquoise, Planquette, Course), high values of sediment yield are observed. The relation between sediment yield and $E C I_{i}$ decreases as the number of erosion control measures increases on a catchment. These results are consistent with the environmental policies of the last decades and confirm their benefits. The upstream and middle catchments all present a low $\operatorname{ECI}_{i}(\sim 1)$. The upstream Canche and Ternoise catchments characterized by large areas show a high flow discharge. Surprisingly the suspended matter flux is much lower than for the other catchments. It is suggested that large catchment areas with high flow discharge are also those where the proportion of erosionsensitive surfaces is lower than for small catchments. We also assume a preferential deposit of their sediment contribution in the upstream part of their respective river channel.

\subsection{Seasonal variability of tributaries contributions}

The seasonal contribution of each tributary at each confluence was estimated for the five sampling campaigns (Fig. 6). An important seasonal variability can be observed along with major fluctuations in relative source contributions. In general, we can observe an important relative contribution of the upstream tributaries (Canche upstream, Ternoise, Planquette, and Créquoise). The downstream tributaries (Bras de Bronne, Course, Dordogne, and Huitrepin) exhibit lower contributions to the sediment yield except for the Bras de Bronne in winter 2015 and summer 2016, and for the Course in winter and spring 2016. For the upstream tributaries, the influence of the Planquette is more effective in dry seasons: summer and spring 2016, the influence of the Créquoise is more effective during wet seasons: winter and autumn 2016. The relative contribution of the Canche is more pronounced during winter and spring 2016 whereas for the Ternoise, the relative contribution is greater in summer and autumn 2016. An effect of storage and/or dilution can be easily observed along the main channel of the Canche river. The relative contributions of the upstream catchments generally decrease when approaching of the downstream sections. Moreover, 
relative contributions of some downstream tributaries, such as the Dordogne or the Bras de Bronne, generally decrease near the sampling point (outlet of the respective tributary).

\section{Discussion}

\subsection{Meaningful implications for erosion control strategies}

The quantification of the tributaries relative contributions using a confluence-based sediment fingerprinting approach was quite conclusive, even in this relatively homogeneous lithological context comprising silty soils which as highly sensitive to erosion processes. The sampling strategy deployed was original and spatially representative of the catchment, following the need for robust sediment fingerprinting approaches as stated by several authors (Smith et al., 2015; Laceby et al., 2017). This approach was based on a relatively simple but effective field methodology on selected strategic sampling points, collecting suspended particulate matter with sediment traps in the Canche watershed at each tributary and each confluence. Time-integrated sediment traps have appeared as very suitable experimental devices to sample a large amount of suspended sediment matter during a restricted sampling period and to study sediment fluxes fluctuations. As stated e.g. by Phillips et al. (2000), Russell et al. (2000), or recent sediment fingerprinting studies on suspended sediment by e.g. Huisman et al. (2013) and Lamba et al. (2015), the use of comparable time-integrated sampling devices is much more representative for this kind of study than point sampling. According to Walling and Webb (1987), sediment transport is highly episodic (90\% of annual load is transported within only $10 \%$ of the time).

The confluence-based approach developed in this study was also particularly effective. As emphasized by Vale et al. (2016), the short distance between upstream and downstream sediment samples limits the effect that non-conservative behavior has on geochemical signature uncertainties. The use of geochemical tracers was relevant in the Canche river watershed, even regarding the homogeneous lithological context, because of significant element composition differences between the tributaries. Differences are assumed to be mainly driven by lithological background level and the 
point or non-point discharge induced by agricultural activities. The results of the simulations showed that tributaries located in the central part of the Canche river watershed (Planquette, Créquoise) were the most contributing to the sediment yield. They also highlight contrasted responses from one season to another, certainly in relation to rains entailing erosive event, which concern in a short time, a localized area.

This work provided conclusions to estimate the spatial evolution of erosive dynamics over a considerably wide area, particularly in relation to the development plans of erosion control facilities. These methodologies can successfully locate the most contributing areas in term of erosion. The results of the study also showed that the environmental policies of the last decades in Northern France seem effective, confirming the recent observations made by Frankl et al. (2017). For catchments with similar areas and fluxes, those with the less erosion control measures installed, exhibit the highest relative contributions to the sediment yield. To our knowledge, this study is the first one comparing results from a confluence-based sediment fingerprinting approach to the land management policies on a watershed. The results are significant, particularly in the given homogeneous context, which enhances the novelty of the approach and thus should be tested for other environmental contexts taking into account the specificities of the studied catchment.

\subsection{Limitations and uncertainties}

The tributaries contributions quantified in this study using the confluence-based sediment fingerprinting approach must be interpreted in the context of some limitations and uncertainties. The target river sediment for source apportionment was collected from a single downstream location for each tributary. The estimated catchment proportions at each confluence therefore strongly relate to the respective sampling site. Koiter et al. (2013) pointed out that sources estimates are scaledependent and can differ for sampling locations along a channel network. This limitation, the socalled "black-box", remains one of the largest limitations of the sediment fingerprinting approach. 

question with a seasonal sampling, although our tributaries estimations are representative of five weeks over two years. It is likely that multiple major flood event could have transported a significant proportion of the annual sediment load and may have not been sampled here. Automatic sediment samplers could be deployed on each key location to increase the temporal representability with the big disadvantage that much more sampling logistics would be needed. Considering these limitations, two approaches need to be explored. First, we may suggest the use of other sediment traps, which

401

402

403

404 offers a larger sediment storage capacity and that can be dropped at key locations during a few months. Secondly, as suggested by Guzmán et al. (2013), we may suggest finding other tracers requiring inexpensive and rapid analysis approach to process quickly a large number of samples. This seems feasible using the spectrocolorimetric or magnetic tracers (Krein et al., 2003; Legout et al., 2013; Patault, 2018). They allow rapid, non-destructive and quantitative measurements of soil and sediment property.

Although tracer properties were tested for transformation using the range test, this does not confirm the complete absence of tracer property transformation during sediment delivery. As shown by Sherriff et al. (2015), the non-conservative behavior of a single tracer property included in a mass balance mixing model can affect the predicted source contributions. According to Zhang and Liu (2016), a more stringent statistical analysis than only the bracket test comprised in the Sed_Sat-v1.0 model, could be proposed to confirm the absence of non-conservative tracers using mixing polygon test. Moreover, Kraushaar et al. (2015) suggested an expanded procedure including water sample analyses to identify tracers that may be susceptible to dissolution during transport. Using the sediment traps deployed in this study, the experiment could be easily done. Further research in this way is strongly recommended.

Particle size effect on element concentration remains one of the biggest uncertainties in sediment fingerprinting approach. Differences between sources and downstream sediments may 
arise from selective transport (Koiter et al., 2015). Our confluence-based approach, as shown in the work of Vale et al. (2016) and Nosrati et al. (2018), decreases the effect that particle size can exert on predicted source contributions. Our analysis proves that the median particle size (D50) was practically the same for all tributary and confluence samples, and thus no correction factor were applied. For future research, the confluence-based approach should be largely explored.

Virtual sample mixtures considering hypothetical tributary provenance (e.g. equal inputs) confirmed the robustness of the applied methodology. Uncertainties were relatively low, showing only slight evidence of variability within each confluence. However, virtual sample mixtures still remain hypothetic, experiments on artificial sample mixtures of known sediment proportions as suggested by Pulley and Collins (2018) would help further refine the modelling results. Also, as suggested by Pulley et al. (2015), tracer selection must maximize contrasts in tracer concentrations between all sources. In the case of the Canche river watershed, which shows a very homogeneous geology; existing but slight differences between the source tracers concentrations were observed. Considering this, we suggest increasing the number and the type of tracers by addition of more discriminating parameters related to the typology of the organic matter.

\section{Conclusions}

The study successfully shows that a confluence-based sediment fingerprinting approach using time-integrated samplers (sediment traps) and physico-chemical analyses on suspended sediment matter, allows discriminating the relative sediment yield contribution of the different tributaries that compose a given catchment, even in a homogeneous lithological context. Best tracers able to discriminate the tributaries (transition metals, metalloids, and alkaline earth metals) were identified using statistical analyses and were incorporated into a mass balance mixing model (Sed_Sat-v1.0 model). Discriminating tracers were assumed to be mainly driven by the lithological background level and the point/non-point discharge induced by agricultural activities. Annual tributary contributions were evaluated and range from 3 to $22 \%$ at the outlet of the main stream. 
Validation using virtual sample mixtures allow considering that the methodology presented is robust.

445 Considering information given by the Artois-Picardie Water Agency, the annual tributary sediment 446 delivery actually ranges from 0.87 to $40.7 \mathrm{kt} \mathrm{yr}^{-1}$. The Planquette and the Créquoise were considered 447 as the most erosive tributaries of the Canche watershed. Tributaries with the highest number of 448 installed erosion control measures on the territory exhibit the lowest values of sediment export confirming the generally positive impact of recent land management policies in Northern France. This novel approach allows to evaluate the relevance of environmental strategies to reduce water erosion in the studied watershed, and easily provides helpful information on decision support for future land management.

\section{Acknowledgements}

This work was financially supported by the Mines-Telecom Institute of Lille-Douai, with additional funding provided by the Artois-Picardie Water Agency (QUASPER project). We would also like to acknowledge technical support from the SYMCEA and the regional Chamber of Agriculture Nord-Pas-de-Calais, France. The authors are grateful to L. Alleman and B. Malet for the ICP-MS/AES analyses (IMT Lille-Douai - SAGE department). The authors thanks A. Gellis and L. Gorman Sanisaca (USGS) who provided the Sed_Sat-v1.0 model and for their helpful discussions. The authors also thanks the four anonymous reviewers who provided constructive suggestions to improve the manuscript.

\section{References}

Agence de l'eau Artois-Picardie. (2016). Schéma Directeur d'Aménagement et de Gestion des Eaux du Bassin Artois-Picardie. Retrieved from http://www.eau-artois-picardie.fr/sdage

Carter, J., Owens, P., Walling, D., \& Leeks, G. (2003). Fingerprinting suspended sediment sources in a large urban river system. The Science of The Total Environment, 314-316(03), 513-534. https://doi.org/10.1016/S0048-9697(03)00071-8

Chambre d'agriculture Nord-Pas-de-Calais. (2013). RUISSOL: Outil de gestion des données liées au suivi des ouvrages de lutte contre l'érosion des sols agricoles. https://www.ruissol.pro/CGI/DLL.dII?APP=3\&MODULE=Ruissol

Choubin, B., Darabi, H., Rahmati, O., Sajedi-Hosseini, Kløve, B. (2018). River suspended sediment modelling using the CART model: A comparative study of machine learning techniques. Science 
Collins, A. L., Walling, D. E., \& Leeks, G. J. L. (1997). Use of the geochemical record preserved in floodplain deposits to reconstruct recent changes in river basin sediment sources. Geomorphology, 19, 151-167. https://doi.org/10.1016/S0169-555X(96)00044-X

Collins, A. L., Walling, D. E., Sichingabula, H. M., Leeks, G. J. L. (2001). Suspended sediment source fingerprinting in a small tropical catchment and some management implications. Applied Geography, 21(4), 387-412. https://doi.org/10.1016/S0143-6228(01)00013-3

Collins, A. L., \& Walling, D. E. (2002). Selecting fingerprint properties for discriminating potential suspended sediment sources in river basins. Journal of Hydrology, 261, 218-244. https://doi.org/10.1016/S0022-1694(02)00011-2

Collins, A. L., Walling, D. E., Webb, L., King, P. (2010). Apportioning catchment scale sediment sources using a modified composite fingerprinting technique incorporating property weightings and prior information. Geoderma, 155(3-4), 249-261. https://doi.org/10.1016/j.geoderma.2009.12.008

Collins, A. L., Zhang, Y., McChesney, D., Walling, D. E., Haley, S. M., Smith, P. (2012). Sediment source tracing in a lowland agricultural catchment in southern England using a modified procedure combining statistical analysis and numerical modelling. Science of The Total Environment, 414, 301-317. https://doi.org/10.1016/j.scitotenv.2011.10.062

Cooper, R. J., Krueger, T., Hiscock, K. M., \& Rawlins, B. G. (2014). Sensitivity of fluvial sediment source apportionment to mixing model assumptions: A Bayesian model comparison. Water Resources Research, 50(11), 9031-9047. https://doi.org/doi:10.1002/2014WR016194

Du, P., \& Walling, D. E. (2016). Fingerprinting surficial sediment sources: Exploring some potential problems associated with the spatial variability of source material properties. Journal of Environmental Management, 1-12. https://doi.org/10.1016/j.jenvman.2016.05.066

Evrard, O., Navratil, O., Ayrault, S., Ahmadi, M., Némery, J., Legout, C., Esteves, M. (2011). Combining suspended sediment monitoring and fingerprinting to determine the spatial origin of fine sediment in a mountainous river catchment. Earth Surface Processes and Landforms, 36(8), 1072-1089. https://doi.org/10.1002/esp.2133

Evrard, O., Poulenard, J., Némery, J., Ayrault, S., Gratiot, N., Duvert, C., Esteves, M. (2013). Tracing sediment sources in a tropical highland catchment of central Mexico by using conventional and alternative fingerprinting methods. Hydrological Processes, 27(6), 911-922. https://doi.org/10.1002/hyp.9421

Frankl, A., Prêtre, V., Nyssen, J., Salvador, P-G. (2017). The success of recent land management efforts to reduce soil erosion in northern France. Geomorphology, 303, 84-93. https://doi.org/10.1016/j.geomorph.2017.11.018

Fryirs, K., \& Gore, D. (2013). Sediment tracing in the upper Hunter catchment using elemental and mineralogical compositions: Implications for catchment-scale suspended sediment (dis)connectivity and management. Geomorphology, 193, 112-121. https://doi.org/10.1016/j.geomorph.2013.04.010

Gellis, A. C., \& Walling, D. E. (2011). Sediment Source Fingerprinting (Tracing) and Sediment Budgets as Tools in Targeting River and Watershed Restoration Programs. Geophysical Monograph Series, 194(JANUARY), 263-291. https://doi.org/10.1029/2010GM000960 
Gellis, A. C., \& Noe, G. B. (2013). Sediment source analysis in the Linganore Creek watershed, Maryland, USA, using the sediment fingerprinting approach: 2008 to 2010. Journal of Soils and Sediments, 13 (10), 1735-1753. https://doi.org/10.1007/s11368-013-0771-6

Gellis, A. C., Noe, G. B., Clune, J. W., Myers, M. K., Hupp, C. R., Schenk, E. R., Schwarz, G. E. (2015). Sources of the grained sediment in the Linganore Creek watershed, Frederick and Carroll Counties, Maryland, 2008-10: U.S. Geological Survey Scientific Investigations Report 2014-5147, 56p., http://dx.doi.org/10.31313/sir20145147.

Gorman Sanisaca, L. E., Gellis, A. C., \& Lorenz, D. L. (2017). Determining the Sources of Fine-Grained Sediment Using the Sediment Source Assessment Tool ( Sed _ SAT ): U.S. Geological Survey Open File Report 2017-1062, 104 p., https://doi.org/10.3133/ofr20171062.

Guzmán, G., Quinton, J. N., Nearing, M. A., Mabit, L., Gómez, J. A. (2013). Sediment tracers in water erosion studies: current approaches and challenges. Journal of Soils and Sediments, 13(4), 816833. https://doi.org/10.1007/s11368-013-0659-5

Haddadchi, A., Ryder, D. S., Evrard, O., Olley, J. (2013). Sediment fingerprinting in fluvial systems: review of tracers, sediment sources and mixing models. International Journal of Sediment Research, 28(4), 560-578. https://doi.org/10.1016/S1001-6279(14)60013-5

Haddadchi, A., Olley, J. \& Laceby, P. (2014). Accuracy of mixing models in predicting sediment source contributions. Science of the Total Environment, 497-498, 139-152. https://dx.doi.org/10.1016/j.scitotenv.2014.07.105

Haddadchi, A., Olley, J., \& Pietsch, T. (2015). Quantifying sources of suspended sediment in three size fractions. Journal of Soils and Sediments, 15(10), 2086-2100. https://doi.org/10.1007/s11368015-1196-1

Hughes, A. O., Olley, J. M., Croke, J. C., McKergow, L. A. (2009). Sediment sources changes over the last 250 years in a dry-tropical catchment, central Queensland, Australia. Geomorphology, 104(3-4), 262-275. https://doi.org/10.1016/j.geomorph.2008.09.003

Huisman, N. L. H., Karthikeyan, K. G., Lamba, J., Thompson, A. M., Peaslee, G. (2013). Quantification of seasonal sediment and phosphorus transport dynamics in an agricultural watershed using radiometric fingerprinting techniques. Journal of Soils and Sediments, 13(10), 1724-1734. https://doi.org/10.1007/s11368-013-0796-0

Kayvantash, D. (2016). Caractérisation des particules ferrugineuses dans la Seine avec le magnétisme environnemental. Thèse de doctorat. Université de recherche Paris Sciences et Lettres, France. $268 p$.

Kayvantash, D., Cojan, I., Kissel, C., Franke, C. (2017). Magnetic fingerprint of the sediment load in a meander bend section of the Seine River (France). Geomorphology, 286, 14-26. https://doi.org/10.1016/j.geomorph.2017.02.020

Koiter, A. J., Owens, P. N., Petticrew, E. L., Lobb, D. A. (2013). The behavioural characteristics of sediment properties and their implications for sediment fingerprinting as an approach for identifying sediment sources in river basins. Earth-Science Reviews, 125, $24-42$. https://doi.org/10.1016/j.earscirev.2013.05.009

Koiter, A. J., Owens, P. N., Petticrew, E. L., Lobb, D. A. (2015). The role of gravel channel beds on the particle size and organic matter selectivity of transported fine-grained sediment: implications for sediment fingerprinting and biogeochemical flux research. Journal of Soils and Sediments, 15(10), 2174-2188. https://doi.org/10.1007/s11368-015-1203-6 
Kraushaar, S., Schumann, T., Ollesch, G., Schubert, M., Vogel, H-J., Siebert, C. (2015). Sediment fingerprinting in northern Jordan: element-specific correction factors in a carbonatic setting. Journal of Soils and Sediments, 15(10), 2155-2173. https://doi.org/10.1007/s11368-015-1179-2

Krein, A., Petticrew, E., \& Udelhoven, T. (2003). The use of fine sediment fractal dimensions and colour to determine sediment sources in a small watershed. Catena, 53(2), 165-179. https://doi.org/10.1016/S0341-8162(03)00021-3

Laceby, J. P., Evrard, O., Smith, H. G., Blake, W. H., Olley, J. M., Minella, J. P. G., Owens, P. N. (2017). The challenges and opportunities of addressing particle size effects in sediment source fingerprinting: A review. Earth-Science Reviews, 169, 85-103. https://doi.org/10.1016/j.earscirev.2017.04.009

Laceby, J. P., \& Olley, J. (2015). An examination of geochemical modelling approaches to tracing sediment sources incorporating distribution mixing and elemental correlations. Hydrological Processes, 29(6), 1669-1685. https://doi.org/10.1002/hyp.10287

Lamba, J., Karthikeyan, K. G., \& Thompson, A. M. (2015). Apportionment of suspended sediment sources in an agricultural watershed using sediment fingerprinting. Geoderma, 239-240, 25-33. https://doi.org/10.1016/j.geoderma.2014.09.024

Le Gall, M., Evrard, O., Foucher, A., Laceby, J. P., Salvador-Blanes, S., Thil, F., Ayrault, S. (2016). Quantifying sediment sources in a lowland agricultural catchment pond using 137Cs activities and radiogenic $87 \mathrm{Sr} / 86 \mathrm{Sr}$ ratios. Science of the Total Environment, 566-567, 968-980. https://doi.org/10.1016/j.scitotenv.2016.05.093

Legout, C., Poulenard, J., Nemery, J., Navratil, O., Grangeon, T., Evrard, O., Esteves, M. (2013). Quantifying suspended sediment sources during runoff events in headwater catchments using spectrocolorimetry. Journal of Soils and Sediments, 13(8), 1478-1492. https://doi.org/10.1007/s11368-013-0728-9

Li, T., Sun, G., Yang, C., Liang, K., Ma, S., Huang, L., Luo, W. (2019). Source apportionment and sourceto-sink transport of major and trace elements in coastal sediments: Combining positive matrix factorization and sediment trend analysis. Science of the Total Environment, 651, 344-356. https://doi.org/10.1016/j.scitotenv.2018.09.198

Martínez-Carreras, N., Udelhoven, T., Krein, A., Gallart, F., Iffly, J. F., Ziebel, J., Walling, D. E. (2010). The use of sediment colour measured by diffuse reflectance spectrometry to determine sediment sources: Application to the Attert River catchment (Luxembourg). Journal of Hydrology, 382(1-4), 49-63. https://doi.org/10.1016/j.jhydrol.2009.12.017

Motha, J. A., Wallbrink, P. J., Hairsine, P. B., Grayson, R. B. (2003). Determining the sources of suspended sediment in a forested catchment in southeastern Australia. Water Resources Research, 39(3), 1056. https://doi.org/10.1029/2001wr000794

Motha, J. A., Wallbrink, P. J., Hairsine, P. B., Grayson, R. B. (2004). Unsealed roads as suspended sediment sources in an agricultural catchment in south-eastern Australia. Journal of Hydrology, 286(1-4), 1-18. https://doi.org/10.1016/j.jhydrol.2003.07.006

Nosrati, K., Collins, A. L., \& Madankan, M. (2018). Fingerprinting sub-basin spatial sediment sources using different multivariate statistical techniques and the Modified MixSIR model. Catena, 164, 32-43. https://doi.org/10.1016/j.catena.2018.01.003

Palazón, L., Latorre, B., Gaspar, L., Blake, W. H., Smith, H. G., Navas, A. (2015). Comparing catchment sediment fingerprinting procedures using an auto-evaluation approach with virtual sample 
mixtures. Science of The Total https://doi.org/10.1016/j.scitotenv.2015.05.003

Patault, E. (2018). Analyse multi-échelle des processus d'érosion hydrique et de transferts sédimentaires en territoire agricole: exemple du bassin versant de la Canche. Thèse de doctorat. IMT Lille Douai, France. 300p.

Phillips, J. M., Russell, M. A., \& Walling, D. E. (2000). Time-integrated sampling of fluvial suspended sediment: a simple methodology for small catchments. Hydrological Processes, 14(14), 25892602. https://doi.org/10.1002/1099-1085(20001015)14:14<2589::AID-HYP94>3.0.CO;2-D

Poulenard, J., Perrette, Y., Fanget, B., Quetin, P., Trevisan, D., Dorioz, J. M. (2009). Infrared spectroscopy tracing of sediment sources in a small rural watershed (French Alps). Science of the Total Environment, 407(8), 2808-2819. https://doi.org/10.1016/j.scitotenv.2008.12.049

Pulley, S., Foster, I., \& Antunes, P. (2015). The application of sediment fingerprinting to floodplain and lake sediment cores: assumptions and uncertainties evaluated through case studies in the Nene Basin, UK. Journal of Soils and Sediments, 15(10), 2132-2154. https://doi.org/10.1007/s11368-015-1136-0

Pulley, S. \& Collins, A. L. (2018). Tracing catchment fine sediment sources using the new SIFT (Sedlment Fingerprinting Tool) open source software. Science of the Total Environment, 635, 838-858. https://doi.org/10.1016/j.scitotenv.2018.04.126

R Core Team (2013). R: A language and environment for statistical computing. R Foundation for statistical computing, Vienna, Asutria. URL: http://www.R-project.org/

Russell, M. A., \& Walling, D. E. (2000). Appraisal of a simple sampling device for collecting timeintegrated fluvial suspended sediment samples. The Role of Erosion and Sediment Transport in Nutrient and Contaminant Transfert (Proceedings of a symposium held at Waterloo, Canada, July 200). IAHS Publ. no. 263.

Russell, M. A., Walling, D. E., \& Hodgkinson, R. . (2001). Suspended sediment sources in two small lowland agricultural catchments in the UK. Journal of Hydrology, 252(1-4), 1-24. https://doi.org/10.1016/S0022-1694(01)00388-2

Shapiro, S. S., \& Wilk, M. B. (1965). An Analysis of Variance Test for Normality ( Complete Samples ), 52(3), 591-611. Retrieved from http://www.jstor.org/stable/2333709

Sherriff, S. C., Franks, S. W., Rowan, J. S., Fenton, O., Ó’hUallacháin, D. (2015). Uncertainty-based assessment of tracer selection, tracer non-conservativeness and multiple solutions in sediment fingerprinting using synthetic and field data. Journal of Soils and Sediments, 15(10), 2101-2116. https://doi.org/10.1007/s11368-015-1123-5

Smith, H. G., Evrard, O., Blake, W. H., Owens, P. N. (2015). Preface-Addressing challenges to advance sediment fingerprinting research. Journal of Soils and Sediments, 15(10), 2033-2037. https://doi.org/10.1007/s11368-015-1231-2

Tessier, L. (2003). Transport et caractérisation des matières en suspension dans le bassin versant de la Seine: identification de signatures naturelles et anthropiques. Thèse de doctorat. Ecole des Ponts ParisTech.

Theuring, P., Collins, A. L., \& Rode, M. (2015). Source identification of fine-grained suspended sediment in the Kharaa River basin, northern Mongolia. Science of The Total Environment, 526, 77-87. https://doi.org/10.1016/j.scitotenv.2015.03.134 
Vale, S. S., Fuller, I. C., Procter, J. N., Basher, L. R., Smith, I. E. (2016). Application of a confluencebased sediment-fingerprinting approach to a dynamic sedimentary catchment, New Zealand. Hydrological Processes, 30(5), 812-829. https://doi.org/10.1002/hyp.10611

Vale, S. S., Fuller, I. C., Procter, J. N., Basher, L. R., Smith, I. E. (2016). Characterization and quantification of suspended sediment sources to the Manawatu River, New Zealand. Science of the Total Environment, 543, 171-186. https://doi.org/10.1016/j.scitotenv.2015.11.003

Venables, W. N. \& Ripley, B. D. (2002). Modern Applied Statistics With S. Technometrics. https://doi.org/10.1198/tech.2003.s33

Walling, D. E., Russell, M. A., Hodgkinson, R. A., Zhang, Y. (2002). Establishing sediment budgets for two small lowland agricultural catchments in the UK. Catena, 47(4), 323-353. https://doi.org/10.1016/S0341-8162(01)00187-4

Walling, D. E. \& Webb, B. W. (1987). Suspended load in gravel bed-rivers: UK experience, in Thorne, C. R., Bathurst, J. C. and Hey, R. D. (Eds). Sediment transportation in Gravel-bed river. Wiley, Chichester, pp. 691-723.

Walling, D. E. \& Woodward, J. C. (1992). Use of radiometric fingerprints to derive information on suspended sediment sources. Erosion and Sediment Transport Monitoring Programmes in River Basins. (Proceedings Oslo Symposium). In Erosion and sediment transport Programmes in River Basins (Vol. 210, pp. 64-153).

Walling, D. E., Woodward, J. C., \& Nicholas, A. P. (1993). A multi-parameter approach to fingerprint suspended-sediment sources. In Tracers in Hydrology (Proceeding of the Yokohama Symposium, July 1993). IAHS Publ. no, 215.

Weihs, C., Ligges, U., Luebke, K., Raabe, N. (2005). klaR: analyzing German business cycles. Data Analysis and Decision Support, 335-343. https://doi.org/10.1007/3-540-28397-8_36

Wilkinson, S. N., Hancock, G. J., Bartley, R., Hawdon, A. A., Keen, R. J. (2013). Using sediment tracing to assess processes and spatial patterns of erosion in grazed rangelands, Burdekin River basin, Australia. Agriculture, Ecosystems and Environment, 180, 90-102. https://doi.org/10.1016/j.agee.2012.02.002

Zhang, X. C., \& Liu, B. L. (2016). Using multiple composite fingerprints to quantify fine sediment source contributions: a new direction. Geoderma, 268, 108-118. https://doi.org/10.1016/j.geoderma.2016.01.031 


\section{Figures}

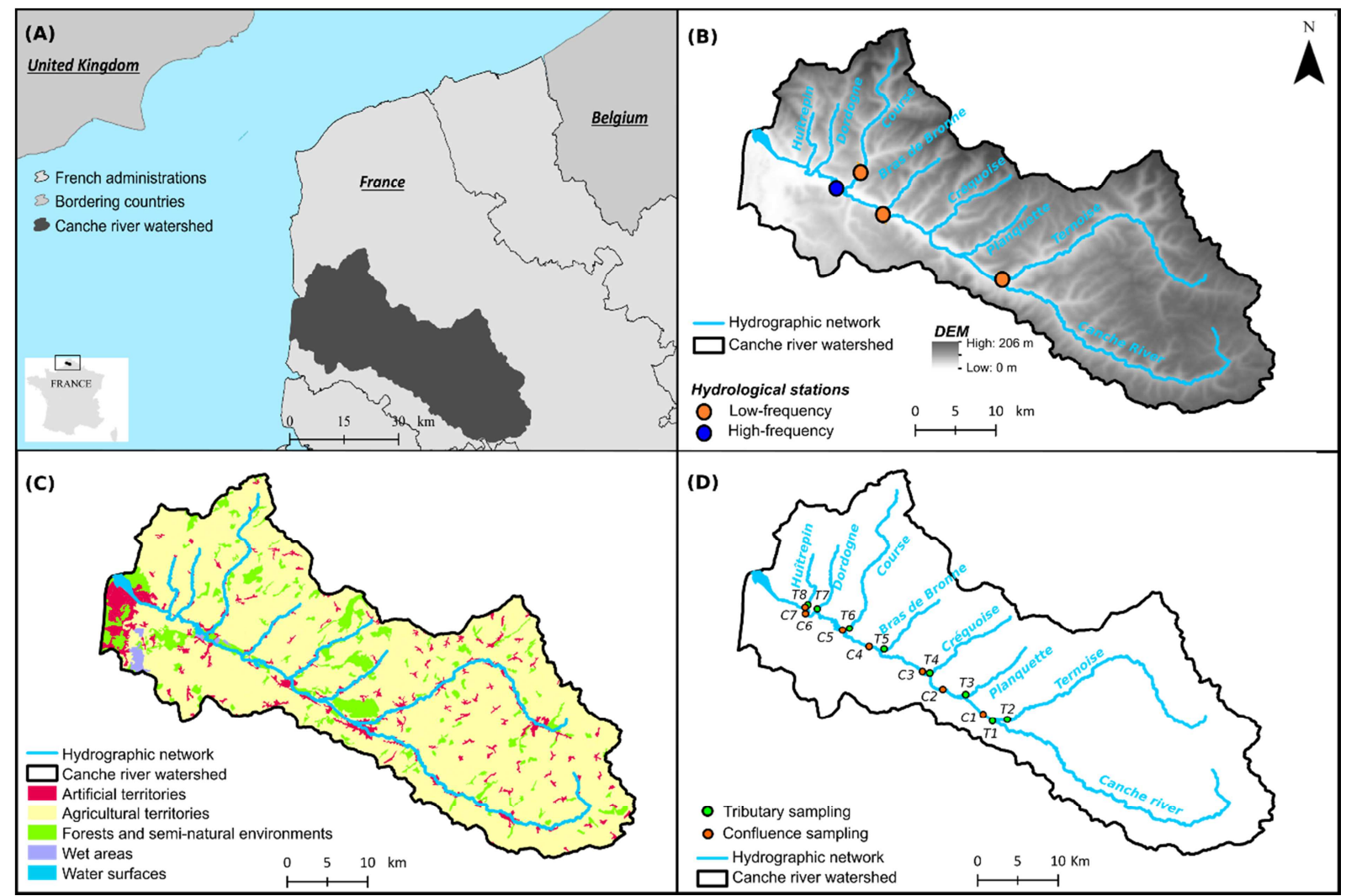

Figure 1: (A) Overview of the Canche river watershed, (B) Digital elevation model (DEM; $m$ ), hydrographic network and location of monitoring stations, (C) Corine Land Cover 2012 and (D) Location of sediment sampling for the study. 


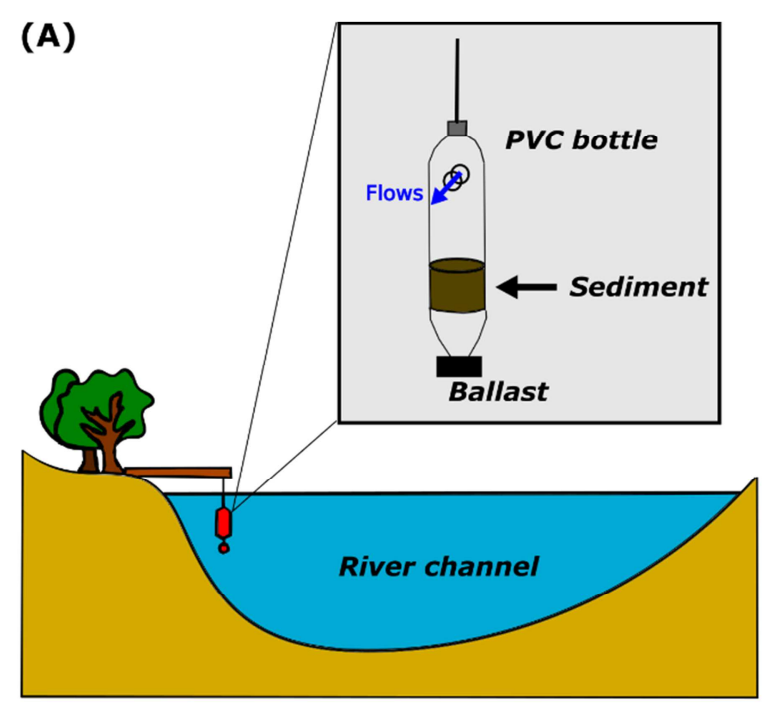

(B)
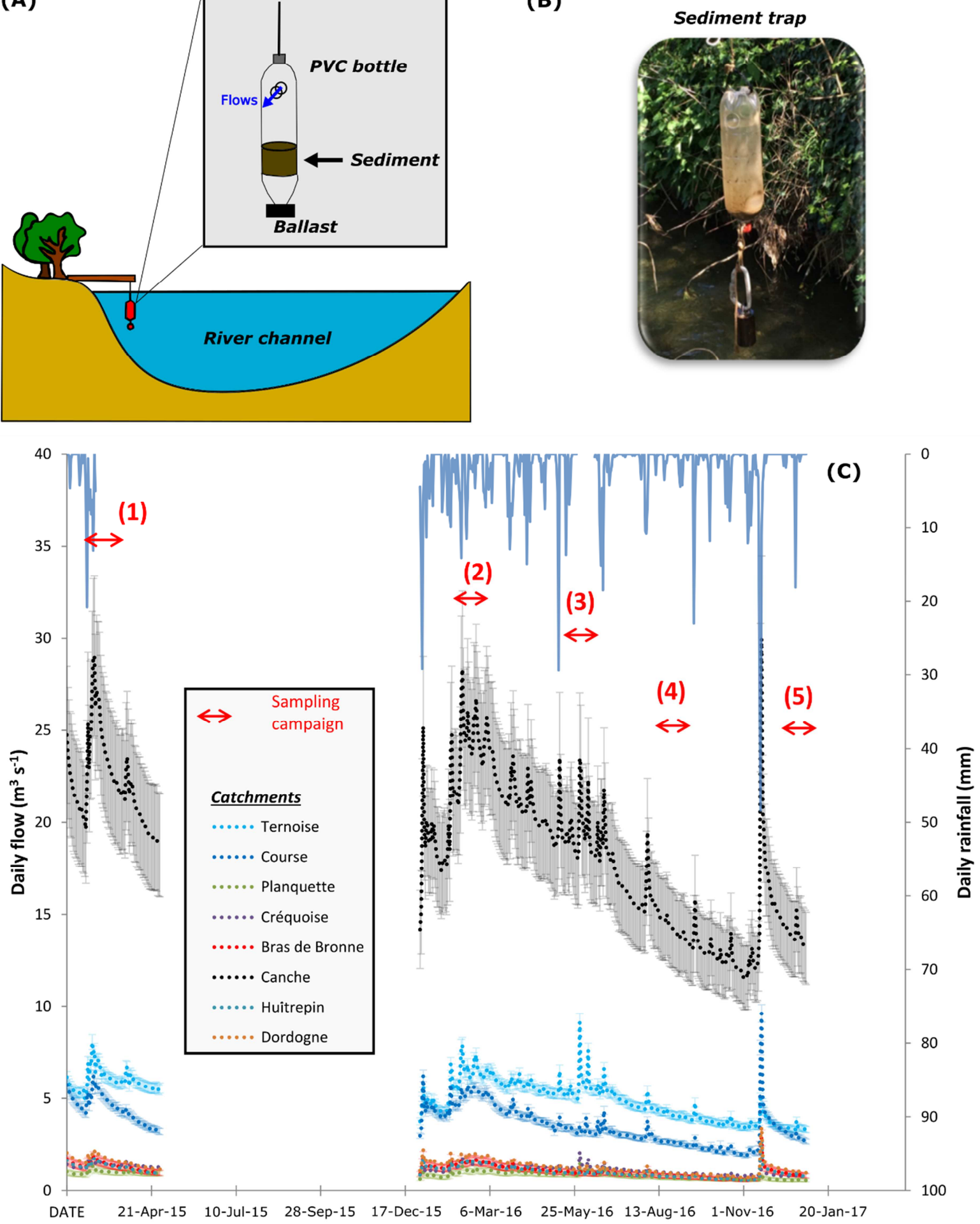

Figure 2 : (A, B) Protocol and experimental device used to sample suspended particulate matter (SPM) for each tributary and confluence in the study, (C) temporal variability of the flow discharge in the Canche river watershed during the five seasonal sampling campaign. 

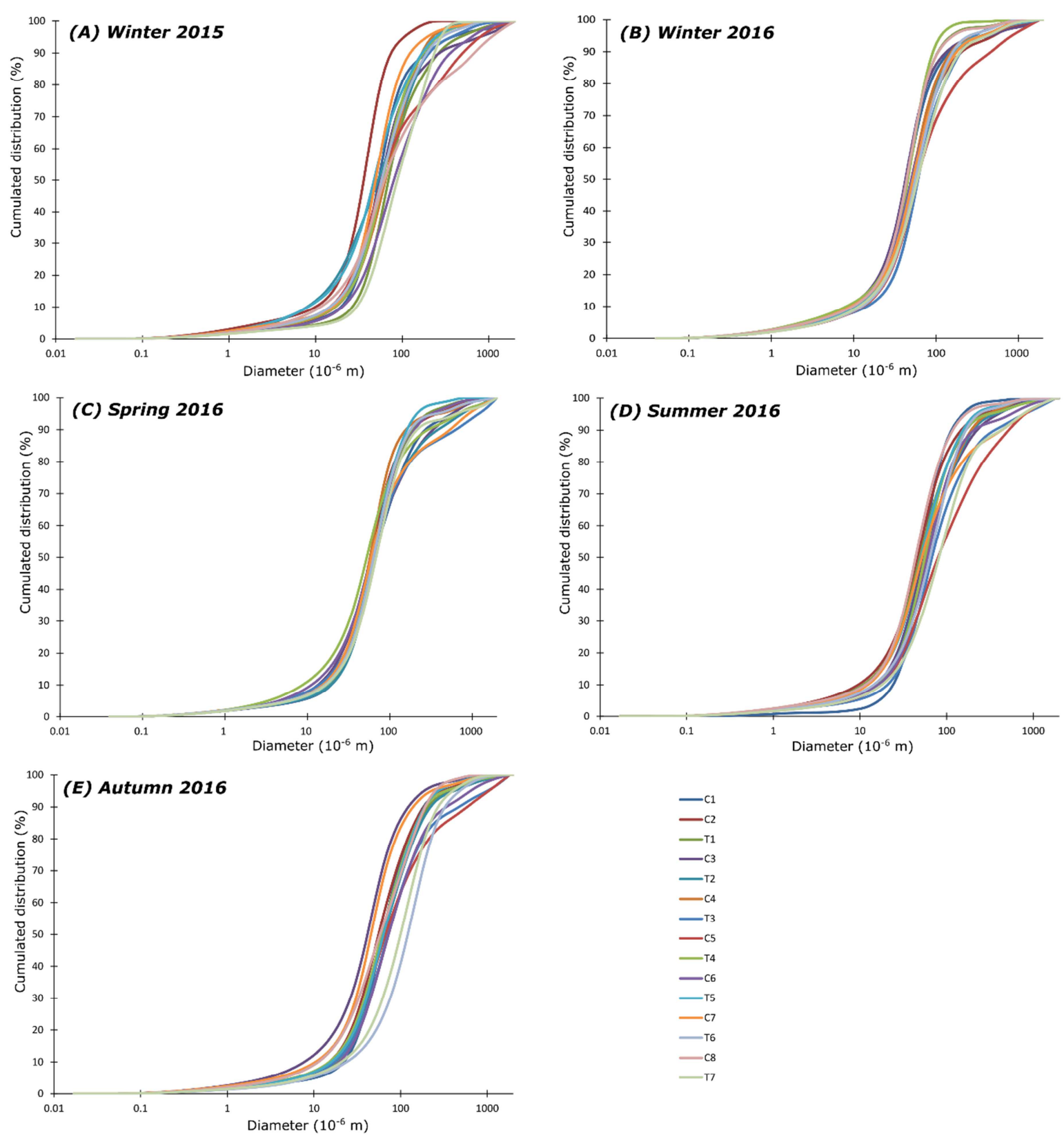

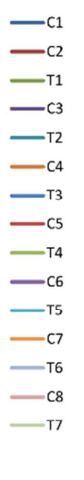

Figure 3: Grain size distribution for all samples collected in the Canche river watershed. 

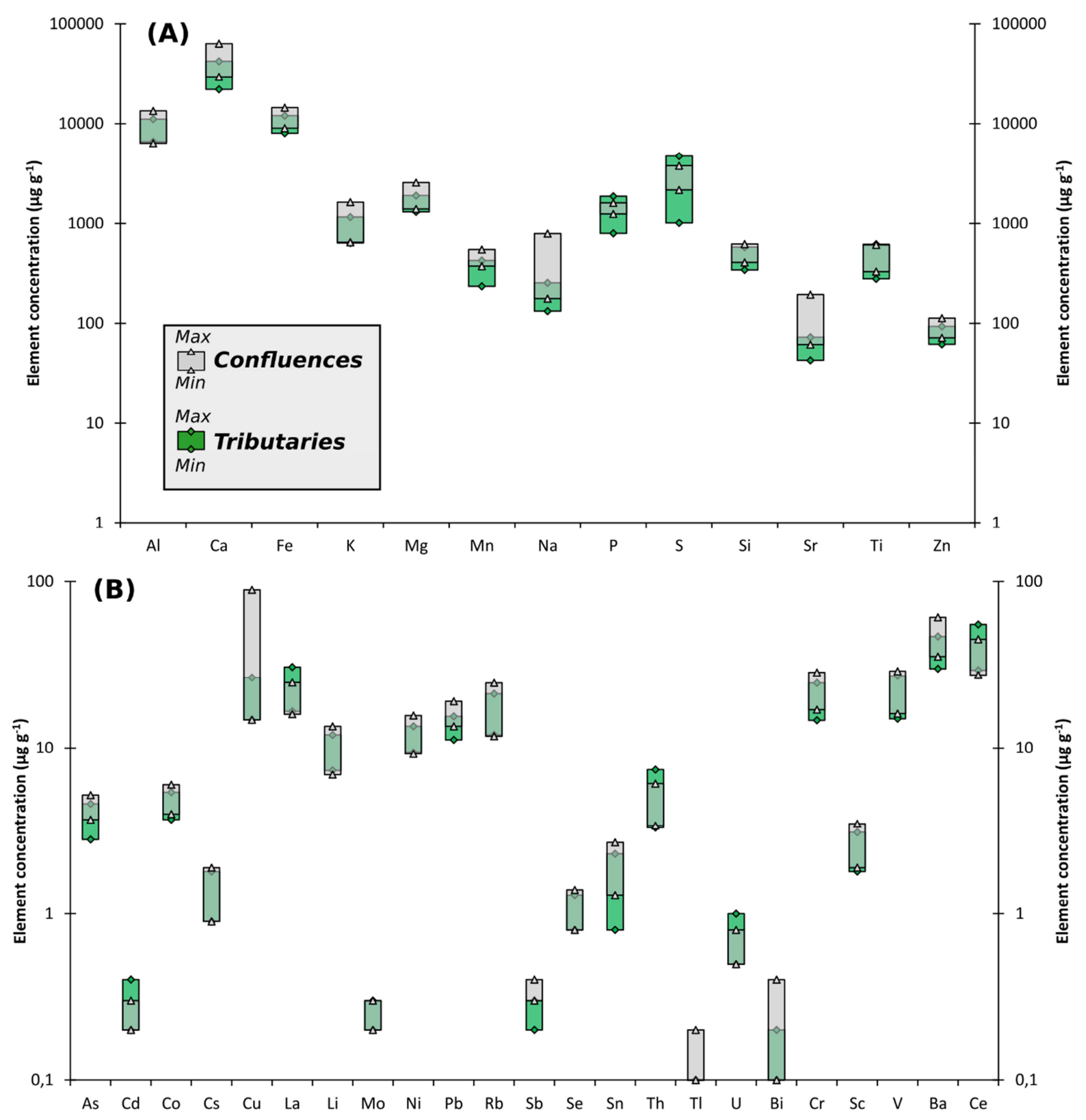

Figure 4: Range of concentrations (expressed in $\mu \mathrm{g} \mathrm{g}^{-1}$ ) of major elements (A) and trace elements (B) in the sediment trap samples during the five seasonal sampling campaigns. 


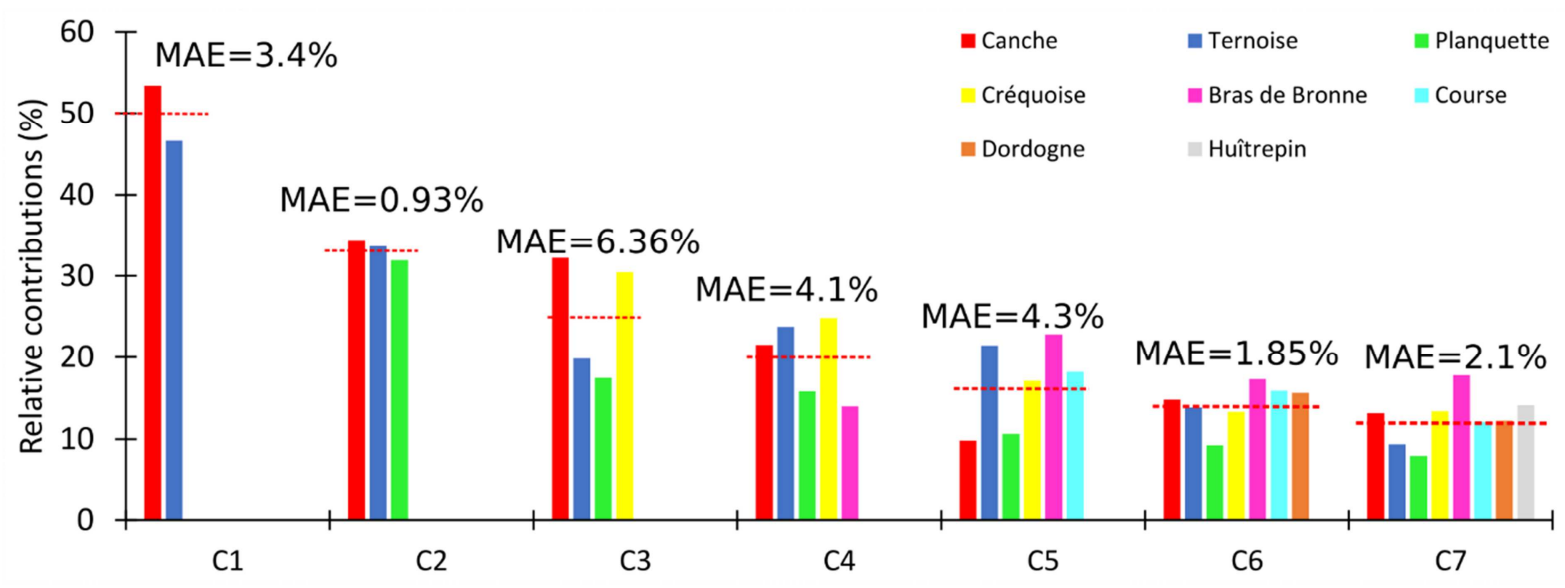

Figure 5 : Mixing model results using virtual mixtures, at each confluences. Red dotted lines indicates the hypothetical contributions (e.g. equal inputs from each tributary). MAE refers to the Mean Absolute Error (\%).
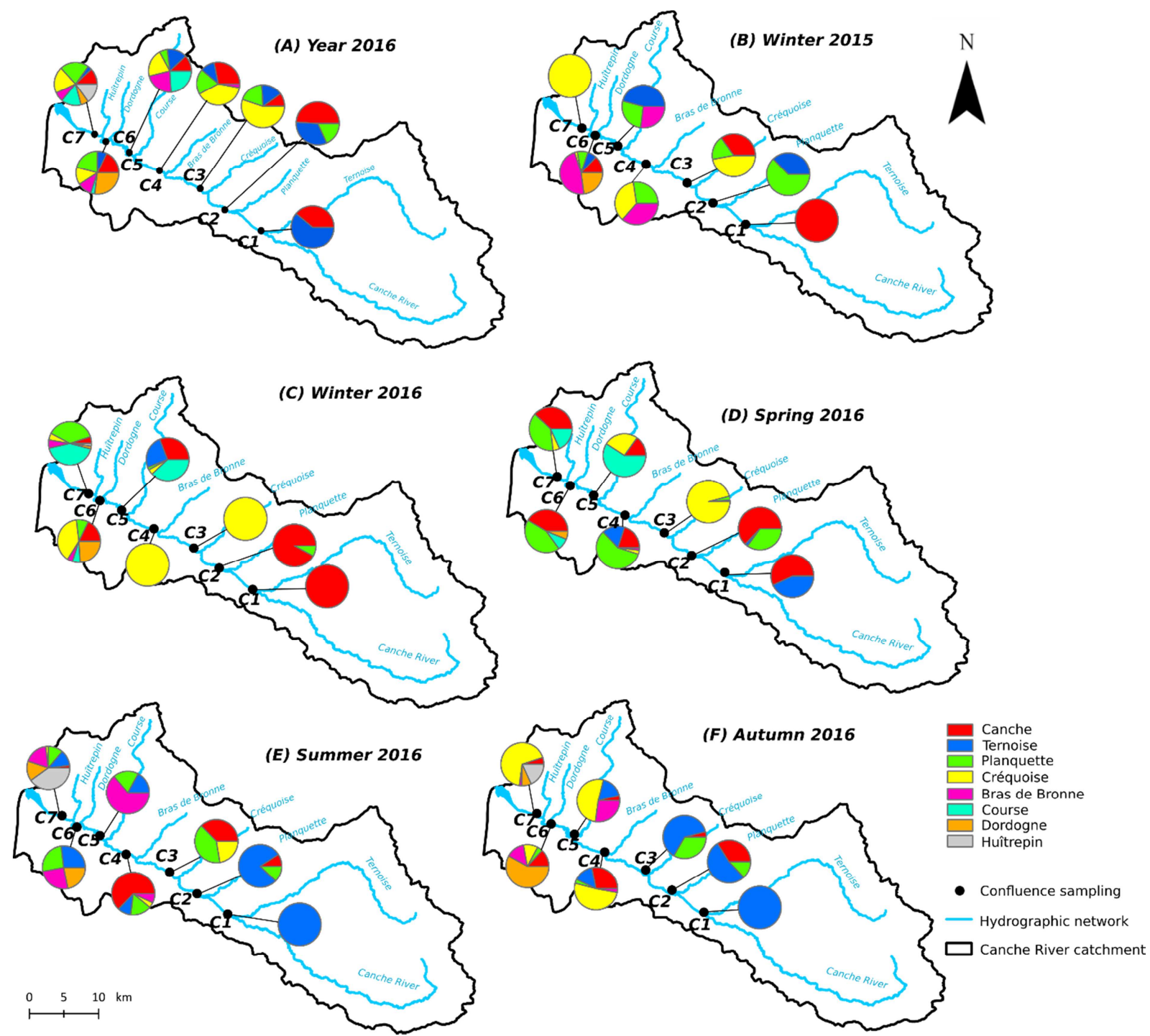

Figure 6 : (A) Annual tributaries relative contributions (\%) to the sediment yield in the Canche river watershed and, $(B, C, D, E, F)$ seasonal tributaries relative contributions (\%) to the sediment yield in the Canche river watershed. 


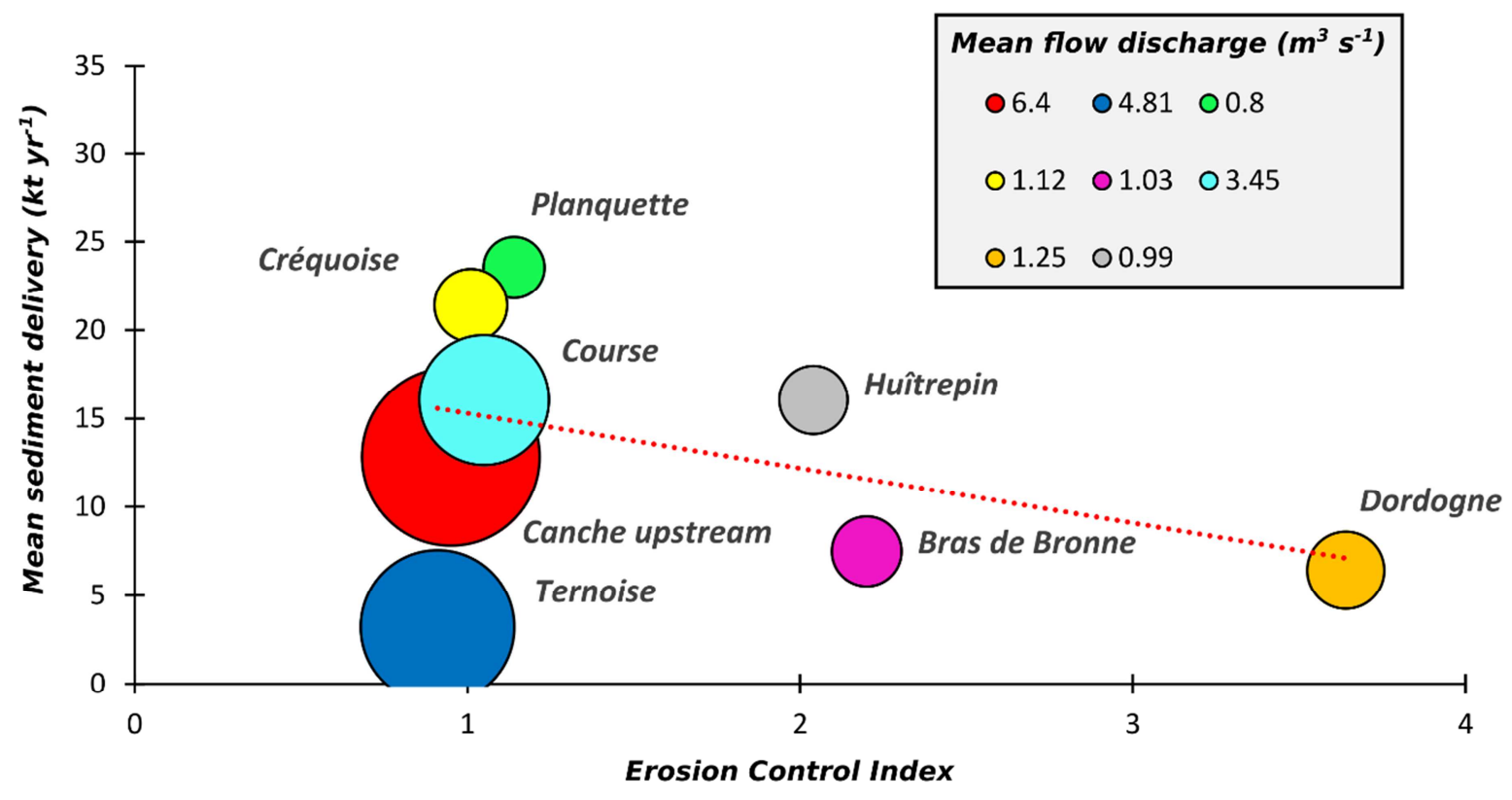

Figure 7: Evaluation of each tributary sediment delivery $\left(\mathrm{kt} \mathrm{yr}^{-1}\right)$ as a function of the Erosion Control Index (number of erosion control measures per $\left.\mathrm{km}^{2}\right)$. The bubbles indicates the annual mean flow discharge $\left(\mathrm{m}^{3} \mathrm{~s}^{-1}\right)$. The red dotted line indicates the trend $(R=0.41)$. 


\section{Tables}

Tab. 1: Results of the Bracket test to determine conservative tracers at each confluence.

\begin{tabular}{ll}
\hline Confluence & Conservative tracers \\
\hline C1 & As, Co, La, Mo, Ni, Sn, Th, U, Ce, Al, Ca, Fe, K, Mg, Na, P, S, Sr, Ti, Zn \\
C2 & Cd, La, Sn, Th, U, Ce, Na, Si, Ti \\
C3 & As, Co, Cu, La, Mo, Pb, Sb, Se, Sn, Th, TI, U, Bi, Cr, V, Ba, Ce, K, Mg, Mn, Na, Si, Sr, Ti, Zn \\
C4 & As, Cd, Co, Cs, La, Li, Pb, Rb, Sb, Sn, Th, TI, U, Bi, Cr, Sc, V, Ba, Ce, Al, Ca, Fe, K, Mg, Mn, Na, P, S, Si, Sr, Ti, Zn \\
C5 & As, Cd, Co, Cs, Cu, La, Ni, Pb, Rb, Sb, Se, Sn, Th, U, Ba, Ce, Al, Ca, Fe, Mg, Mn, Na, P, S, Si, Sr, Ti, Zn \\
C6 & As, Cd, Co, Cs, La, Li, Mo, Ni, Pb, Rb, Sb, Se, Sn, Th, U, Bi, Cr, V, Ba, Ce, Al, Fe, Mn, P, S, Si, Ti, Zn \\
C7 &
\end{tabular}

Tab. 2: Results of the stepwise DFA to identify the final composite fingerprint at each confluence.

\begin{tabular}{|c|c|c|c|c|c|c|c|c|c|c|c|c|c|c|c|c|c|c|c|c|}
\hline $\mathrm{C} 1$ & & & $\mathrm{C} 2$ & & & $\mathrm{C} 3$ & & & C4 & & & $\mathrm{C} 5$ & & & $\mathrm{C} 6$ & & & $\mathrm{C7}$ & & \\
\hline Tracer & $\%^{a}$ & $\mathrm{TDW}^{\mathrm{b}}$ & Tracer & $\%^{a}$ & TDW $^{b}$ & Tracer & $\%^{a}$ & TDW $^{b}$ & Tracer & $\%^{\mathrm{a}}$ & TDW $^{b}$ & Tracer & $\%^{a}$ & $\mathrm{TDW}^{\mathrm{b}}$ & Tracer & $\%^{\mathrm{a}}$ & TDW $^{b}$ & Tracer & $\%^{\mathrm{a}}$ & $\mathrm{TDW}^{\mathrm{b}}$ \\
\hline Co & 60 & 1.5 & La & 47 & 3.5 & $\mathrm{Bi}$ & 44 & 2.3 & $\mathrm{Ca}$ & 36 & 3 & $\mathrm{Ca}$ & 34 & 8.1 & Mo & 13 & 2 & Mo & 14 & 2.6 \\
\hline $\mathrm{Ni}$ & 50 & 1.3 & $U$ & 40 & 3 & $\mathrm{Sr}$ & 20 & 1.1 & $\mathrm{Bi}$ & 30 & 2.5 & $\mathrm{Mn}$ & 16 & 3.7 & $\mathrm{~Pb}$ & 26 & 4 & $\mathrm{~Pb}$ & 23 & 4.1 \\
\hline $\mathrm{Mg}$ & 60 & 1.5 & $\mathrm{Na}$ & 13 & 1 & $\mathrm{Sb}$ & 19 & 1 & $\mathrm{Mn}$ & 19 & 1.6 & $\mathrm{Mg}$ & 15 & 3.5 & As & 16 & 2.4 & As & 9 & 1.6 \\
\hline $\mathrm{Ca}$ & 40 & 1 & $\mathrm{Ti}$ & 20 & 1.5 & As & 23 & 1.2 & $\mathrm{Si}$ & 23 & 1.9 & $\mathrm{Sb}$ & 13 & 2.9 & $\mathrm{Se}$ & 7 & 1.1 & Se & 6 & 1.1 \\
\hline
\end{tabular}




\begin{tabular}{|c|c|c|c|c|c|c|c|c|c|c|c|c|c|c|c|c|c|c|c|}
\hline \multirow[t]{8}{*}{ Total $^{c}$} & \multirow[t]{8}{*}{100} & $\mathrm{Cd}$ & 47 & 3.5 & $\mathrm{Se}$ & 20 & 1.1 & K & 12 & 1 & $\mathrm{Si}$ & 17 & 3.9 & $\mathrm{Ni}$ & 6 & 1 & Co & 8 & 1.3 \\
\hline & & $\mathrm{Si}$ & 13 & 1 & $\mathrm{Ti}$ & 34 & 1.8 & $\mathrm{Sb}$ & 15 & 1.3 & Cs & 13 & 2.9 & $\mathrm{Fe}$ & 27 & 4.2 & $\mathrm{Ni}$ & 9 & 1.6 \\
\hline & & Total $^{c}$ & 53 & & Total $^{\mathrm{c}}$ & 85 & & $\mathrm{Fe}$ & 24 & 2 & $\mathrm{Rb}$ & 8 & 1.9 & Co & 11 & 1.7 & $\mathrm{Fe}$ & 21 & 3.8 \\
\hline & & & & & & & & Total $^{c}$ & 69 & & $\mathrm{Sr}$ & 14 & 3.3 & $P$ & 7 & 1.1 & $\mathrm{Mn}$ & 12 & 2.1 \\
\hline & & & & & & & & & & & $\mathrm{Na}$ & 4 & 1 & $\mathrm{Mn}$ & 14 & 2.1 & $\mathrm{Zn}$ & 8 & 1.3 \\
\hline & & & & & & & & & & & As & 12 & 2.7 & Total $^{c}$ & 54 & & Al & 11 & 1.9 \\
\hline & & & & & & & & & & & $\mathrm{Ni}$ & 8 & 1.7 & & & & $\mathrm{Cd}$ & 6 & 1 \\
\hline & & & & & & & & & & & $\mathrm{Cd}$ & 8 & 1.7 & & & & $\mathrm{Cr}$ & 18 & 3.1 \\
\hline
\end{tabular}

${ }^{\mathrm{a}} \%$ source type samples correctly classified by the tracer.

${ }^{\mathrm{b}}$ tracer discriminatory weighting used in the mass balance modelling.

${ }^{\mathrm{c}} \%$ source type samples classified correctly by the final composite fingerprint. 


\section{Graphical abstract}

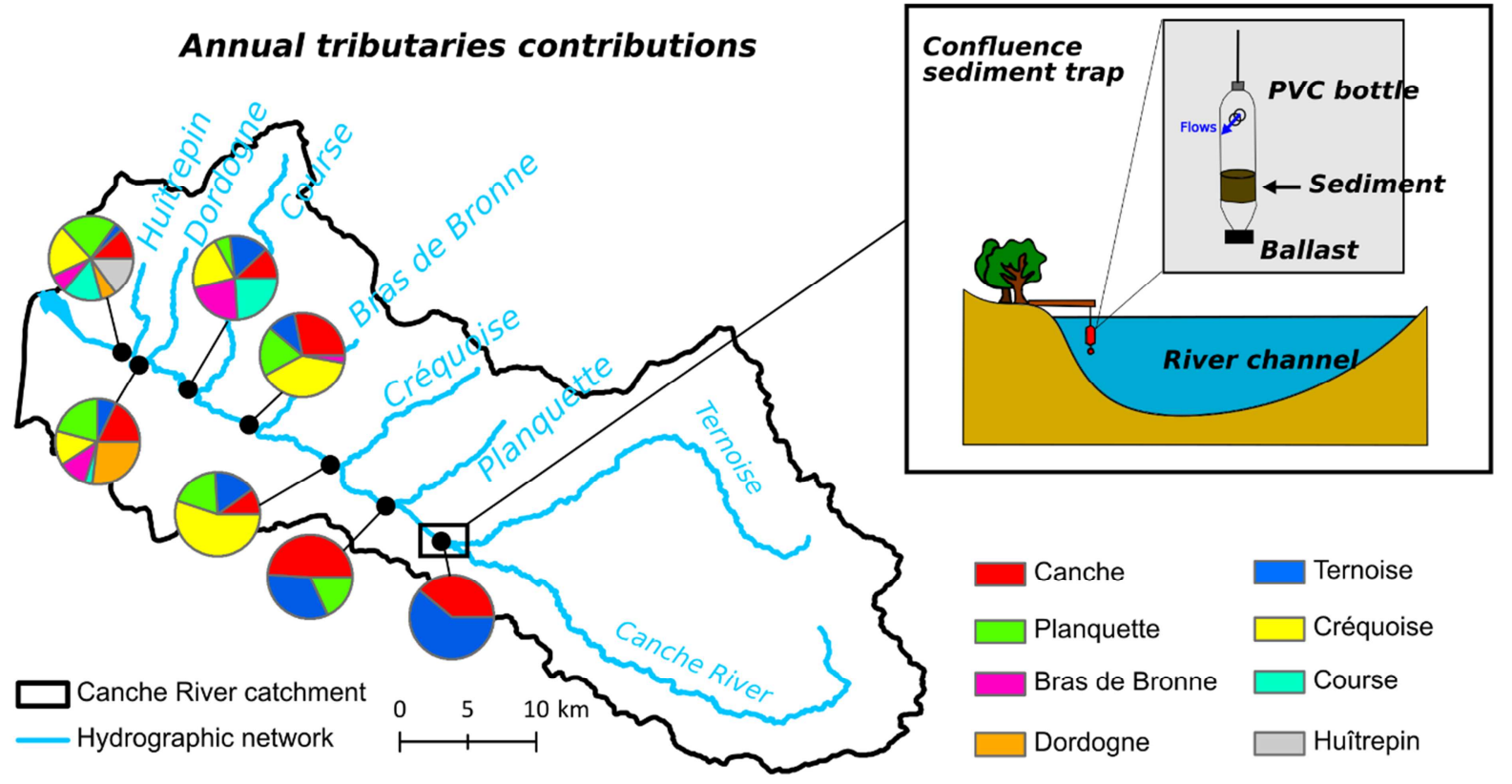

